\title{
ANALISIS PENGELOLAAN KEUANGAN DESA SE-KECAMATAN NUSA PENIDA TAHUN 2017
}

\author{
Pande Wiwik Widiantari ${ }^{1}$, Kadek Rai Suwena ${ }^{1}$, Anjuman Zukhri² \\ Jurusan Pendidikan Ekonomi \\ Universitas Pendidikan Ganesha \\ Singaraja, Indonesia \\ e-mail: \{wiwikwidiantari27@gmai.com¹, kadeksuwena@yahoo.co.id', \\ anjumanzukhri@undiksha.ac.id²\}
}

\begin{abstract}
Abstrak
Penelitian ini bertujuan ini untuk mengetahui penganggaran keuangan desa pada kantor desa di Kecamatan Nusa Penida tahun anggaran 2017 dan realisasi pelaksanaan keuangan desa pada kantor desa se-Kecamatan Nusa Penida tahun anggaran 2017. Data diperoleh dengan melakukan wawancara dan dokumentasi. Metode analisis data yang digunakan adalah metode analisis deskriptif. Populasi dari penelitian ini yaitu enam belas desa di Kecamatan Nusa Penida dan sampelnya adalah empat desa di Kecamatan Nusa Penida tahun 2017. Hasil penelitian menunjukkan bahwa penganggaran keuangan desa pada kantor desa di Kecamatan Nusa Penida tahun anggaran 2017 mengalami defisit dan realisasi pelaksanaan keuangan desa pada kantor desa di Kecamatan Nusa Penida tahun anggaran 2017 mengalami defisit karena jumlah realisasi pendapatan desa di Kecamatan Nusa Penida lebih kecil dari pada jumlah belanja desa di Kecamatan Nusa Penida.
\end{abstract}

Kata kunci: keuangan desa, otonomi desa dan peraturan

\begin{abstract}
This research aims to was to find out the budgeting of village finances in village offices in Nusa Penida Sub-district fiscal year 2017 and the realization of implementation village financial at village offices in as Nusa Penida Sub-district fiscal year 2017. Data was obtained by conducting interview and documentation. Methods of data analysis used were descriptive analysis method. The population of this study are sixteen villages in Nusa Penida Subdistrict and the sample is four villages in Nusa Penida sub-district in 2017. The results showed that the village finance budgeting in village offices in Nusa Penida sub-district in fiscal year 2017 had a deficit and the realization of village finance in village office in Nusa Penida subdistrict in the budget year of 2017 had a deficit because the total revenue of villages in Nusa Penida sub-district was smaller shopping village in Nusa Penida District.
\end{abstract}

\section{Keywords : village finance, village autonomy and regulations}

\section{PENDAHULUAN}

Menurut Widjaja (2003:4) "Secara historis desa merupakan cikal bakal terbentuknya masyarakat politik dan pemerintahan di Indonesia jauh sebelum negara bangsa ini terbentuk". Struktur sosial sejenis desa, masyarakat adat, dan lain sebagainya telah menjadi institusi sosial yang mempunyai posisi yang sangat penting. Menurut Undang-Undang
Nomor 22 Pasal 94 Tahun 1999, "bentuk pemerintahan desa terdiri atas pemerintah desa dan badan perwakilan desa dimana pemerintahan desa terdiri atas kepala desa dan perangkat desa (sekretaris desa, bendaharawan desa, kepala seksi dan kepala dusun)", sedangkan Badan Perwakilan Desa (BPD) sesuai Pasal 104 adalah wakil penduduk yang dipilih dari dan oleh penduduk desa yang mempunyai 
fungsi mengayomi adat istiadat, membuat peraturan desa dan mengawasi penyelenggaraan pemerintah desa.

Undang-undang Nomor 6 Tahun 2014 tentang desa termasuk produk Undang-undang yang sangat istimewa. Salah satu keistimewaan Undang-undang desa yaitu menetapkan desa sebagai entitas masyarakat dan pemerintah desa yang memiliki otonomi dalam mengatur pembangunan untuk mensejahterakan masyarakat. Pembangunan desa bertujuan untuk meningkatkan kesejahteraan masyarakat desa dan kualitas hidup manusia serta penanggulangan kemiskinan melalui pemenuhan kebutuhan dasar, pembangunan sarana dan prasarana desa, pengembangan potensi ekonomi lokal, pemanfaatan sumber daya alam dan lingkungan yang berkelanjutan, meliputi: tahap perencanaan, Berdasarkan Undang-Undang Republik Indonesia nomor 12 Tahun 2008 Perencanaan pembangunan daerah didasarkan pada data dan informasi yang akurat dan dapat dipertanggungjawabkan. Menurut Suharto (2010:71) "Perencanaan pada hakekatnya adalah sebuah proses yang penting dan menentukan keberhasilan suatu tindakan dengan demikian, kunci keberhasilan dalam pengelolaan atau manajemen tergantung dalam proses perencanaannya untuk mensejahterakan anggotanya". Pelaksanaan: Seluruh kegiatan yang berkaitan denga pengeluaran dan penerimaan desa dalam rangka pelaksanaan kewenangan desa dilaksanakan melalui rekening kas desa.

Penerimaan dan pengeluaran desa hendaknya mempunyai bukti yang lengkap dan sah agar nantinya bisa dipertanggungjawabkan. Penatausahaan merupakan penerimaan dan pengeluaran wajib dilakukan oleh bendahara desa. Pelaporan Menurut Widjaja (2003:155) "secara umum pelaporan merupakan satu fase penting dalam siklus manajemen". Selain dapat dijadikan alat evaluasi dari hasil kinerja seseorang atau pimpinan lembaga atau organisasi terhadap pihakpihak yang memberi mandat dan menjadi alat evaluasi bagi diri sendiri guna memperbaiki kinerja pada periode selanjunya. Manajemen pemerintahan desa, pelaporan memiliki fungsi sebagai media akuntabilitas atau pertanggungjawaban selama melaksanakan tugas yang telah ditetapkan dan dipertanggungjawaban yang mengedepankan kebersamaan, kekeluargaan dan kegotongroyongan guna mewujudkan perdamaian dan transparansi dalam pengelolaan keuangan. Laporan pertanggungjawaban merupakan suatu laporan yang dibuat dan dipertanggungjawabkan dalam suatu forum tertentu dan dalam jangka waktu tertentu (Widjaja 2003:155). Pemerintah desa diharapkan secara mandiri mengelola pemerintahan dan berbagai sumber daya yang dimiliki, termasuk didalamnya pengelolaan keuangan dan kekayaan milik desa. Begitu besar peran yang diterima desa, tentunya disertai dengan tanggungjawab yang besar pula. Oleh karena itu pemerintah desa wajib menerapkan prinsip akuntabilitas dalam tata kelola pemerintah desa yang harus dipertanggungjawabkan kepada masyarakat sesuai ketentuan yang berlaku.

Pengelolaan keuangan merupakan salah satu kegiatan administrasi yang sangat penting dalam kepemerintahan. Pengelolaan keuangan dilakukan dengan prinsip tata kelola yang baik agar menjamin akuntabilitas. Menurut Peraturan Menteri Dalam Negeri Nomor 113 Tahun 2014 tentang "Pengelolaan Keuangan Desa adalah keseluruhan kegiatan yang meliputi perencanaan, pelaksanaan, penatausahaan, pelaporan, dan pertanggungjawaban keuangan desa". Tepatnya pengelolaan keuangan desa akan berdampak positif dalam kemajuan dan pembangunan desa, begitupun sebaliknya apabila pengelolaan keuangan kurang tepat maka akan berdampak negatif dalam kemajuan dan pembangunan desa yang nantinya dapat merugikan pemerintah dan masyarakat desa.

Penyajian laporan keuangan menjadi salah satu fase penting dalam siklus manajemen untuk dijadikan alat evaluasi dari hasil kinerja keuangan. Pelaporan dalam manajemen pemerintah desa memiliki fungsi sebagai media akuntabilitas atau pertanggungjawaban 
selama melaksanakan tugas yang telah ditetapkan dalam bentuk laporan keuangan. Pertanggungjawaban pelaporan keuangan yang baik dan benar akan mengurangi dan menghindari adanya penyelewengan atau pelanggaran yang dilakukan oleh pemerintah desa seperti korupsi, kolusi dan nepotisme. Penyusunan laporan keuangan harus menggunakan asas pengelolaan keuangan yaitu transparansi, akuntabel, partisipatif, tertib dan disiplin.

Jumlah anggaran pendapatan dan belanja desa pada salah satu desa yang dilakukan penelitian awal di Nusa Penida tahun anggaran 2016 yaitu pendapatan desa sebesar Rp. 2.247.567.879,24 dan belanja desa Rp. 2.876.374.229,1. Besarnya Anggaran Pendapatan dan Belanja Desa (APBDesa) di Nusa Penida harus dikelola dengan baik dan benar agar tidak terjadi penyimpangan pada saat pelaksanaan dan dapat menyebabkan kerugian bagi pembangunan desa maupun pemerintah desa. Pemerintah desa dalam mengelola keuangan desa wajib menyusun laporan realisasi pelaksanaan anggaran pendapatan dan belanja desa dan laporan pertanggungjawaban realisasi pelaksanaan anggaran pendapatan dan belanja desa. Laporan ini dihasilkan dalam pengelolaan keuangan desa yang dimulai dari perencanaan, pelaksanaan, penatausahaan, pelaporan dan pertanggungjawaban agar kekeliruan dalam pelaksaan dapat diminimalisir.

Berdasarkan latar belakang di atas maka tujuan dari penelitian ini adalah untuk menganalisis pengelolaan keuangan desa serta kontribusi terhadap pembangunan desa se- Kecamatan Nusa Penida.

\section{METODE}

Penelitian ini merupakan penelitian deskriptif dengan pendekatan kuantitatif yaitu suatu penelitian yang bertujuan untuk memperoleh gambaran untuk memahami dan menjelaskan pengelolaan keuangan desa. Lokasi penelitian ini yaitu di Kecamatan Nusa Penida, Kabupaten Klungkung, Provinsi Bali. Populasinya adalah enam belas desa yang ada di
Kecamatan Nusa Penida. Sampel penelitian yang dijadikan unit penelitian adalah empat desa di Kecamatan Nusa Penida. Diambilnya empat desa tersebut karena dalam penelitian ini, peneliti mengelompokan desa menjadi empat wilayah yaitu desa bagian utara, timur, selatan, dan barat. Desa yang mewakili setiap wiyah yaitu Desa Kutampi (bagian utara), Desa Suana (bagian timur), Desa Tangglad (bagian selatan), dan Deasa Klumpu (bagian Barat). Jenis data yang digunakan dalam penelitian ini menggunakan data kuantitatif berdasarkan hasil wawancara dan studi dokumen. Sumber data yang digunakan data primer dan data sekunder. Metode pengumpulan data menggunakan metode wawancara dan metode dokumentasi. Reduksi data dilakukan untuk mendapatkan data yang lebih tepat dan jelas, mempermudah penelitian untuk melakukan pengumpulan data yang selanjutnya, dan mencari kembali ketika dibutuhkan oleh penelitian. Penyajian data dilakukan terhadap data yang diperoleh dari proses wawancara dan studi dokumen.

Teknik analisis data yang digunakan adalah analisis deskriptif. Analisis Deskriptif Menurut Sugiyono (2005: 21) "analisis deskriptif adalah suatu metode yang digunakan untuk menggambarkan atau menganalisis suatu hasil penelitian tetapi tidak digunakan untuk membuat kesimpulan yang lebih jelas.

Kriteria yang digunakan dalam penelitian ini adalah sebagai berikut.

Silpa :Pelampauan penerimaan pendapatan terhadap belanja

Defisit :Realisasi pendapatan lebih kecil dari pada realisasi belanja.

\section{HASIL DAN PEMBAHASAN Hasil}

Berdasarkan hasil penelitian di empat desa se-Kecamatan Nusa Penida yaitu desa Kutampi Kaler, Desa Suana, Desa Tanglad dan Desa klumpu mengenai penganggaran keuangan desa tahun anggaran 2017 menunjukkan hasil seperti yang tertera pada tabel 1 berikut ini. 
Tabel 1. Anggaran Pendapatan dan Belanja Desa Kutampi Kaler ( bagian utara)Tahun 2017

\begin{tabular}{|c|c|c|c|c|}
\hline \multirow[b]{2}{*}{ No } & \multicolumn{2}{|c|}{ Pendapatan } & \multicolumn{2}{|c|}{ Belanja } \\
\hline & Mata anggaran & Jumlah (Rp) & Mata anggaran & Jumlah (Rp) \\
\hline 1 & $\begin{array}{l}\text { Pendapatan asli } \\
\text { desa }\end{array}$ & $27.000 .000,00$ & $\begin{array}{l}\text { Bidang } \\
\text { penyelenggaraan } \\
\text { pemerintah desa }\end{array}$ & $620.114 .040,21$ \\
\hline 2 & Dana desa & $916.845 .977,00$ & Bidang pembanguna & 1.813.783.224,78 \\
\hline 3 & Alokasi dana desa & $1.072 .265 .548,24$ & $\begin{array}{l}\text { Bidang pembinaan } \\
\text { masyarakat }\end{array}$ & $551.539 .399,00$ \\
\hline 4 & Pajak dan retribusi & $172.939 .813,00$ & $\begin{array}{l}\text { Bidang pemerdayaan } \\
\text { masyarakat }\end{array}$ & $135.394 .800,00$ \\
\hline 5 & $\begin{array}{l}\text { Bantuan keuangan } \\
\text { khusus }\end{array}$ & $650.000 .000,00$ & Bidang tak terduga & 0,00 \\
\hline & Total & $2.846 .251 .338,24$ & Total & $3.120 .831 .463,99$ \\
\hline
\end{tabular}

Berdasarkan tabel 1 dapat dilihat bahwa penganggaran pendapatan Desa Kutampi Kaler bersumber dari pendapatan asli desa yang berjumlah $\mathrm{Rp}$. 27.000.000,00; dana desa sebesar Rp. 916.845.977,00; alokasi dana desa sebesar Rp. 1.072.265.548,24; pajak dan retribusi sebesar Rp. 172.939.813,00; dan bantuan keuangan khusus sebesar $\mathrm{Rp}$. 650.000.000,00. Total anggaran pendapatan Desa Kutampi Kaler tahun 2017 sebesar Rp. 2.846.251.338,24.
Angaran belanja Desa Kutampi Kaler yaitu bidang penyelenggaraan pemerintah desa sebesar Rp. 620.114.040,21; bidang pembanguna sebesar Rp. 1.813.783.224,78; bidang pembinaan masyarakat sebesar Rp. 551.539.399,00; bidang pemerdayaan masyarakat sebesar Rp. 135.394.800,00; dan bidang tak terduga sebesar Rp. 0,00. Total jumlah anggaran belanja Desa Kutampi Kaler sebesar Rp. 3.120.831.463,99; sehingga keuangan Desa kutampi Kaler mengalami defisit Rp.

274.580.125,75.

Tabel 2 Anggaran Pendapatan dan Belanja Desa Suana ( bagian timur) Tahun 2017

\begin{tabular}{|c|c|c|c|c|}
\hline \multicolumn{3}{|c|}{ Pendapatan } & \multicolumn{2}{|c|}{ Belanja } \\
\hline No & Mata anggaran & Jumlah (Rp) & Mata anggaran & Jumlah (Rp) \\
\hline 1 & $\begin{array}{l}\text { Pendapatan asli } \\
\text { desa }\end{array}$ & $6.212 .923,79$ & $\begin{array}{l}\text { Bidang } \\
\text { penyelenggaraan } \\
\text { pemerintah desa }\end{array}$ & $738.847 .794,13$ \\
\hline 2 & Dana desa & $909.754 .422,00$ & Bidang pembanguna & $1.948 .872 .152,65$ \\
\hline 3 & Alokasi dana desa & $1.108 .173 .032,05$ & $\begin{array}{l}\text { Bidang pembinaan } \\
\text { masyarakat }\end{array}$ & $501.185 .878 ., 58$ \\
\hline 4 & $\begin{array}{l}\text { Pajak dan } \\
\text { retribusi }\end{array}$ & $183.941 .225,00$ & $\begin{array}{l}\text { Bidang pemerdayaan } \\
\text { masyarakat }\end{array}$ & $77.172 .000,00$ \\
\hline \multirow[t]{2}{*}{5} & $\begin{array}{l}\text { Bantuan } \\
\text { keuangan khusus }\end{array}$ & $900.000 .000,00$ & Bidang tak terduga & 0,00 \\
\hline & Total & $3.108 .081 .602,84$ & Total & $3.266 .077 .825,36$ \\
\hline $\begin{array}{l}\text { bah } \\
\text { Sua } \\
\text { des } \\
\text { dan }\end{array}$ & $\begin{array}{l}\text { Berdasarkan tabel } \\
\text { wa penganggaran } \mathrm{f} \\
\text { na bersumber dari } \\
\text { a yang berjumlah } \mathrm{F} \\
\text { a desa sebesar Rp. }\end{array}$ & $\begin{array}{l}2 \text { dapat dilihat } \\
\text { Jendapatan Desa } \\
\text { pendapatan asli } \\
\text { Rp. } 6.212 .923,79 \text {; } \\
\text { 909.754.422,00; }\end{array}$ & $\begin{array}{l}\text { alokasi dana } \\
1.108 .173 .032,05 ; \\
\text { sebesar Rp. } \\
\text { bantuan keuangar } \\
900.000 .000,00 .\end{array}$ & $\begin{array}{c}\text { desa sebesar Rp. } \\
\text { pajak dan retribusi } \\
\text { 183.941.225,00; dan } \\
\text { khusus sebesar Rp. } \\
\text { Total anggaran }\end{array}$ \\
\hline
\end{tabular}


p-ISSN : 2599-1418

e-ISSN : 2599-1426

pendapatan Desa Suana tahun 2017 sebesar Rp. 3.108.081.602,84. Angaran belanja Desa Suana yaitu bidang penyelenggaraan pemerintah desa sebesar Rp. 738.847.794,13; bidang pembanguna sebesar Rp. 1.948.872.152,65; bidang pembinaan masyarakat sebesar Rp. 501.185.878,58; bidang pemerdayaan masyarakat sebesar
Jurnal Pendidikan Ekonomi Undiksha

Volume 10 No. 1 Tahun 2018

Rp. 77.172.000,00; dan bidang tak terduga sebesar Rp. 0,00.

Total jumlah anggaran belanja Desa Suana sebesar Rp. 3.266.077.825,36, dengan demikian keuangan Desa Suana mengalami defisit sebesar Rp. 157.996.222,52 tutup dengan sisa lebih pembiayaan anggaran Desa Suana tahun anggaran 2016.

Tabel 3. Anggaran Pendapatan dan Belanja Desa Tanglad ( bagian selatan)Tahun 2017

\begin{tabular}{|c|c|c|}
\hline \multirow[b]{2}{*}{ No } & Pendapatan & Belanja \\
\hline & Mata anggaran Jumlah $(\mathrm{Rp})$ & Mata anggaran Jumlah (Rp) \\
\hline 1 & $\begin{array}{l}\text { Pendapatan asli } \\
\text { desa }\end{array}$ & $\begin{array}{l}\text { Bidang } \\
\text { penyelenggaraan } \\
\text { pemerintah desa }\end{array}$ \\
\hline 2 & $861.815 .632,00$ & $\begin{array}{l}\text { Bidang } \\
\text { pembanguna }\end{array}$ \\
\hline 3 & $\begin{array}{l}\text { Alokasi dana } \\
\text { desa }\end{array}$ & $\begin{array}{l}\text { Bidang } \\
\text { pembinaan } \\
\text { masyarakat }\end{array}$ \\
\hline 4 & $\begin{array}{l}\text { Pajak dan } \\
\text { retribusi }\end{array}$ & $\begin{array}{l}\text { Bidang } \\
\text { pemerdayaan } \\
\text { masyarakat }\end{array}$ \\
\hline 5 & $\begin{array}{l}\text { Bantuan } \\
\text { keuangan } \\
\text { khusus }\end{array}$ & $\begin{array}{l}\text { Bidang tak } \\
\text { terduga }\end{array}$ \\
\hline & $3.062 .130464,00$ & $3.258 .868 .737,00$ \\
\hline & 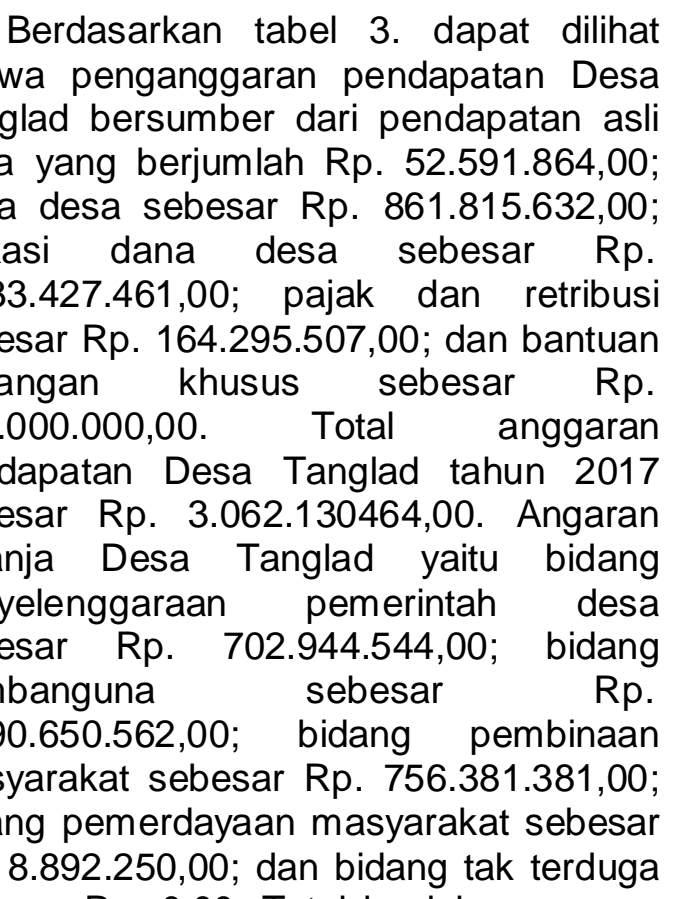 & $\begin{array}{l}\text { belanja } \\
\text { sebesar Rp. 3.258.868.737,00, dengan } \\
\text { demikian keuangan Desa Tanglad } \\
\text { mengalami defisit sebesar Rp. } \\
\text { 196.738.273 kemudian akan di tutup } \\
\text { dengan selisish lebih pembiayaan } \\
\text { anggaran Desa Tanglad tahun } 2016 \text {. } \\
\text { Selisih lebih pembiayaan anggaran tahun } \\
2016 \text { harus dimanfaatkan dengan baik } \\
\text { agar keuangan tahun 2018 tidak } \\
\text { mengalami defisit. Penganggaran } \\
\text { keuangan Desa Tanglad dilakukan } \\
\text { berdasarkan musyawarah desa yang } \\
\text { dilakukan pada bulan juli tahun } \\
\text { sebelumnya sesuai dengan rencana kerja } \\
\text { pemerintahan, kemudian disusun oleh } \\
\text { sekretaris desa yang nantinya akan di } \\
\text { setujui oleh kepala desa dan akan } \\
\text { disetujui bersama dalam musyawarah } \\
\text { desa. }\end{array}$ \\
\hline
\end{tabular}


Tabel 4 Anggaran Pendapatan dan Belanja Desa Klumpu (bagian barat)Tahun 2017

\begin{tabular}{|c|c|c|c|c|}
\hline \multirow[b]{2}{*}{ No } & \multicolumn{2}{|c|}{ Pendapatan } & \multicolumn{2}{|c|}{ Belanja } \\
\hline & Mata anggaran & Jumlah (Rp) & Mata anggaran & Jumlah (Rp) \\
\hline 1 & $\begin{array}{l}\text { Pendapatan asli } \\
\text { desa }\end{array}$ & 11.000 .000 & $\begin{array}{l}\text { Bidang } \\
\text { penyelenggaraan } \\
\text { pemerintah desa }\end{array}$ & $796.640 .622,00$ \\
\hline 2 & Dana desa & $989.317 .874,00$ & Bidang pembanguna & $2.201 .147 .297,00$ \\
\hline 3 & Alokasi dana desa & $1.217 .790 .877,00$ & $\begin{array}{l}\text { Bidang pembinaan } \\
\text { masyarakat }\end{array}$ & $601.321 .000,00$ \\
\hline 4 & $\begin{array}{l}\text { Pajak dan } \\
\text { retribusi }\end{array}$ & $205.945 .740,00$ & $\begin{array}{l}\text { Bidang pemerdayaan } \\
\text { masyarakat }\end{array}$ & $100.129 .000,00$ \\
\hline 5 & $\begin{array}{l}\text { Bantuan } \\
\text { keuangan khusus }\end{array}$ & $900.000 .000,00$ & Bidang tak terduga & 0,00 \\
\hline
\end{tabular}

Total

3.324.054.491,00

Total

3.699.237.919,00

Berdasarkan tabel 4 dapat dilihat bahwa Total anggaran pendapatan Desa Klumpu tahun 2017 sebesar Rp. 3.324.054.491,00 sedangkat total jumlah anggaran belanja Desa Klumpu sebesar Rp. 3.699.237.919,00. Sehingga keuangan Desa Klumpu tahun anggaran 2017 mengalami defisit sebesar $\mathrm{Rp}$. 375.184.428,00 dan akan ditutupi dengan silpa tahun anggaran 2016.

Realisasi pelaksanaaan keuangan merupakan keseluruhan kegiatan yang telah dilakukan oleh seluruh desa yang ada di Kecamatan Nusa Penida berdasarkan APBDesa yang telah ditetapkan sebelumnya. Realisasi pelaksanaan keuangan desa tahun anggaran 2017 di empat desa sampel penelitian di Kecamatan Nusa Penida yaitu desa Kutampi Kaler (bagian utara), Desa Suana (bagian timur), Desa Tanglad (bagian selatan) dan Desa klumpu (bagian barat) menunjukkan hasil seperti yang tertera pada tabel berikut ini.

Tabel 5 Realisasi Pendapatan dan Belanja Desa Kutampi Kaler ( bagian utara)Tahun 2017

\begin{tabular}{|c|c|c|c|c|}
\hline \multicolumn{3}{|c|}{ Pendapatan } & \multicolumn{2}{|r|}{ Belanja } \\
\hline No & Mata anggaran & Jumlah (Rp) & Mata anggaran & Jumlah (Rp) \\
\hline 1 & $\begin{array}{l}\text { Pendapatan asli } \\
\text { desa }\end{array}$ & $20.295 .144,96$ & $\begin{array}{l}\text { Bidang } \\
\text { penyelenggaraan } \\
\text { pemerintah desa }\end{array}$ & $584.051 .150,00$ \\
\hline 2 & Dana desa & $916.845 .977,00$ & Bidang pembanguna & $1.696 .734 .825,00$ \\
\hline 3 & Alokasi dana desa & $1.072 .265 .548,24$ & $\begin{array}{l}\text { Bidang pembinaan } \\
\text { masyarakat }\end{array}$ & $506.487 .000,000$ \\
\hline 4 & Pajak dan retribusi & $153.635 .608,00$ & $\begin{array}{l}\text { Bidang } \\
\text { pemerdayaan } \\
\text { masyarakat }\end{array}$ & $106.282 .800,00$ \\
\hline 5 & $\begin{array}{l}\text { Bantuan } \\
\text { keuangan khusus }\end{array}$ & $650.000 .000,00$ & Bidang tak terduga & 0,00 \\
\hline & Total & 2.826.234.278,19 & Total & 2.893.555.775,00 \\
\hline & $\begin{array}{l}\text { erdasarkan tabel } \\
\text { anggaran pendapa } \\
r \text { bersumber dari } \\
\text { yang berjumlah } \mathrm{R} \\
\text { desa sebesar Rp } \\
\text { asi dana desa }\end{array}$ & $\begin{array}{l}5 \text { terlihat bahwa } \\
\text { tan Desa Kutampi } \\
\text { pendapatan asli } \\
\text { p. 20.295.144,96; } \\
\text { 916.845.977,00; } \\
\text { sebesar Rp. }\end{array}$ & $\begin{array}{l}\text { 1.072.265.548, } \\
\text { sebesar Rp. } 15 \\
\text { keuangan } \\
650.000 .000,00 \\
\text { pendapatan D } \\
2017 \text { sebesa }\end{array}$ & $\begin{array}{l}\text { 4; pajak dan retribusi } \\
\text { 3.635.608,00; dan bantuan } \\
\text { husus sebesar Rp. } \\
\text { Total anggaran } \\
\text { Rp. 2.826.234.278,19. }\end{array}$ \\
\hline
\end{tabular}


p-ISSN : 2599-1418

e-ISSN : 2599-1426

Angaran belanja Desa Kutampi Kaler yaitu bidang penyelenggaraan pemerintah desa sebesar Rp. 584.051.150,00; bidang pembanguna sebesar Rp. 1.696.734.825,00; bidang pembinaan masyarakat sebesar Rp. 1.696.734.825,00; bidang pemerdayaan masyarakat sebesar Rp. 106.282.800,00; dan bidang tak terduga sebesar Rp. 0,00. Total jumlah anggaran belanja Desa Kutampi Kaler sebesar Rp. 2.893.555.775,00. Jadi keuangan Desa Kutampi Kaler pada tahun anggaran 2017 mengalami defisit.

Jumlah defisit keuangan Desa Kutampi Kaler sebesar Rp. 67.321.496,81 dan akan ditutupi dengan selisih lebih pembiayaan anggaran keuangan Desa Kutampi Kaler tahun anggaran 2016. Jadi jumlah defisit keuangan Desa Kutampi Kaler tahun anggaran 2017 yang riel harus ditutupi dengan selisih lebih pembiayaan anggaran Desa Kutampi Kaler tahun anggaran 2016 sebesar Rp. $67.321 .496,81$.
Jurnal Pendidikan Ekonomi Undiksha

Volume 10 No. 1 Tahun 2018

Berdasarkan tabel 1 dan 5 dapat dilihat bahwa anggaran pendapatan dan belanja Desa Kutampi Kaler dengan realisasi pendapatan dan belanja Desa Kutampi Kaler mengalami perbedaan. Jumlah anggaran pendapatan Desa Kutampi Kaler pada tahun anggaran 2017 sebesar Rp. 2.846.251.338,24 dan jumlah anggaran belanja Desa Kutampi kaler tahun anggaran 2017 sebesar Rp. 3.120.831.463,99, sedangkan jumlah realisasi pendapatan Desa Kutampi Kaler tahun anggaran 2017 sebesar Rp.2.826.234.278,19 dan jumlah realisasi belanja Desa Kutampi Kaler tahun anggaran 2017 sebesar Rp. 2.893.555.775,00. Jadi jumlah defisit keuangan Desa Kutampi Kaler tahun anggaran 2017 yang riel harus ditutupi dengan selisih lebih pembiayaan anggaran Desa Kutampi Kaler tahun anggaran 2016 sebesar Rp. $67.321 .496,81$.

Tabel 6. Realisasi Pendapatan dan Belanja Desa Suana (bagian timur) Tahun 2017

\begin{tabular}{|c|c|c|c|}
\hline \multirow[b]{2}{*}{ No } & \multicolumn{2}{|c|}{ Pendapatan } & Belanja \\
\hline & Mata anggaran & Jumlah (Rp) & Mata anggaran \\
\hline 1 & $\begin{array}{l}\text { Pendapatan asli } \\
\text { desa }\end{array}$ & $8.779 .600,66$ & $\begin{array}{l}\text { Bidang } \\
\text { penyelenggaraan } \\
\text { pemerintah desa }\end{array}$ \\
\hline 2 & Dana desa & $909.754 .422,00$ & Bidang pembanguna \\
\hline 3 & $\begin{array}{l}\text { Alokasi dana desa } \\
\text { Pajak dan } \\
\text { retribusi } \\
\text { Bantuan }\end{array}$ & $\begin{array}{c}1.108 .173 .032,05 \\
163.367 .648,00\end{array}$ & $\begin{array}{l}\text { Bidang pembinaan } \\
\text { masyarakat } \\
\text { Bidang pemerdayaan } \\
\text { masyarakat }\end{array}$ \\
\hline 5 & $\frac{\text { keuangan khusus }}{\text { Total }}$ & $\frac{900.000 .000,00}{3.090 .074 .702,71}$ & $\frac{\text { Bidang tak terduga }}{\text { Total }}$ \\
\hline & $\begin{array}{l}\text { Berdasarkan tabel } \\
\text { ganggaran pendap } \\
\text { umber dari pend } \\
\text { g berjumlah Rp. } 8 \\
\text { a sebesar Rp. } 909.7 \\
\text { a desa sebesar Rp. } \\
\text { k dan retribus } \\
367.648,00 \text {; dan b } \\
\text { sus sebesar Rp. } 90 \\
\text { garan pendapatan } \\
7 \text { sebesar Rp. }\end{array}$ & $\begin{array}{l}6 \text { terlihat bahwa } \\
\text { atan Desa Suana } \\
\text { apatan asli desa } \\
.779 .600,66 \text {; dana } \\
54.422,00 ; \text {; alokasi } \\
\text { 1.108.173.032,05; } \\
\text { sebesar Rp. } \\
\text { antuan keuangan } \\
.000 .000,00 \text {. Total } \\
\text { esa Suana tahun } \\
\text { 3.090.074.702,71. }\end{array}$ & $\begin{array}{l}\text { Angaran belanja Desa Suana yaitu bidang } \\
\text { penyelenggaraan pemerintah desa } \\
\text { sebesar Rp. } 679.744 .700 .00 ; \\
\text { pembanguna bidang } \\
1.918 .949 .701,00 ; \quad \text { bidang pembinaan } \\
\text { masyarakat sebesar Rp. } 56.929 .600,00 ; \\
\text { bidang pemerdayaan masyarakat sebesar } \\
\text { Rp. } 72.862 .000,00 ; \text { dan bidang tak } \\
\text { terduga sebesar Rp. } 0,00 \text {. Total jumlah } \\
\text { anggaran belanja Desa Suana sebesar } \\
\text { Rp. } 3.128 .482 .001,00 \text {. Berdasarkan data }\end{array}$ \\
\hline
\end{tabular}


p-ISSN : 2599-1418

e-ISSN : 2599-1426

diatas keuangan Desa Suana pada tahun 2017 mengalami defisit sebesar Rp. 38.407.298,29. Keuangan Desa Suana yang mengalami defisit akan ditutupi dengan silpa tahun 2016.

Berdasarkan tabel 2 dan 6 dapat dilihat bahwa anggaran pendapatan dan belanja Desa Suana dengan realisasi pendapatan dan belanja Desa Suana mengalami perbedaan. Jumlah anggaran pendapatan Desa Suana pada tahun anggaran 2017 sebesar Rp. 3.108.081.602,84 dan jumlah anggaran
Jurnal Pendidikan Ekonomi Undiksha

Volume 10 No. 1 Tahun 2018

belanja Desa Suana tahun anggaran 2017 sebesar Rp. 3.166.077.825,36, sedangkan jumlah realisasi pendapatan Desa Suana tahun anggaran 2017 sebesar Rp. 3.090.074.702,71 dan jumlah realisasi belanja Desa Suana tahun anggaran 2017 sebesar Rp. 3.128.482.001,00. Jadi jumlah defisit keuangan Desa Suana tahun anggaran 2017 yang riel harus ditutupi dengan selisih lebih pembiayaan anggaran Desa Suana tahun anggaran 2016 sebesar Rp. 38.407.298,29.

Tabel 7. Realisasi Pendapatan dan Belanja Desa Tanglad (bagian selatan) Tahun 2017

\begin{tabular}{|c|c|c|c|c|}
\hline \multirow[b]{2}{*}{ No } & \multicolumn{2}{|c|}{ Pendapatan } & \multicolumn{2}{|c|}{ Belanja } \\
\hline & Mata anggaran & Jumlah (Rp) & Mata anggaran & Jumlah (Rp) \\
\hline 1 & $\begin{array}{l}\text { Pendapatan asli } \\
\text { desa }\end{array}$ & $45.585 .881,42$ & $\begin{array}{l}\text { Bidang } \\
\text { penyelenggaraan } \\
\text { pemerintah desa }\end{array}$ & $652.859 .630,00$ \\
\hline 2 & Dana desa & $861.815 .632,00$ & Bidang pembanguna & $1.689 .508 .270,00$ \\
\hline 3 & $\begin{array}{l}\text { Alokasi dana } \\
\text { desa }\end{array}$ & $1.133 .427 .461,00$ & $\begin{array}{l}\text { Bidang pembinaan } \\
\text { masyarakat }\end{array}$ & $675.044 .000,00$ \\
\hline 4 & $\begin{array}{l}\text { Pajak dan } \\
\text { retribusi }\end{array}$ & $145.789 .545,00$ & $\begin{array}{l}\text { Bidang pemerdayaan } \\
\text { masyarakat }\end{array}$ & $8.467 .250,00$ \\
\hline 5 & $\begin{array}{l}\text { Bantuan } \\
\text { keuangan } \\
\text { khusus }\end{array}$ & $850.000 .000,00$ & Bidang tak terduga & 0,00 \\
\hline & Total & $3.036 .618 .519,33$ & Total & $3.025 .879 .150,00$ \\
\hline
\end{tabular}

Berdasarkan tabel 7 terlihat bahwa penganggaran pendapatan Desa Tanglad bersumber dari pendapatan asli desa yang berjumlah $\mathrm{Rp}$. 45.585.881,42; dana desa sebesar Rp. 861.815.632,00; alokasi dana desa sebesar Rp. 1.133.427.461,00 pajak dan retribusi sebesar $R p$. 145.789.545,00; dan bantuan keuangan khusus sebesar Rp. 850.000.000,00. Total anggaran pendapatan Desa Tanglad tahun 2017 sebesar Rp. 3.036.618.519,33. Angaran belanja Desa Tanglad yaitu bidang penyelenggaraan pemerintah desa sebesar Rp. $652.859 .630,00$; bidang pembanguna sebesar Rp. 1.689.508.270,00; bidang pembinaan masyarakat sebesar $\mathrm{Rp}$. 675.044.000,00; bidang pemerdayaan masyarakat sebesar Rp. 8.467.250,00; dan bidang tak terduga sebesar Rp. 0,00. Total jumlah anggaran belanja Desa Tanglad sebesar Rp. 3.025.879.150,00. Jadi keuaangan Desa Tanglad pada tahun 2017 mengalami silpa sebesar $R p$. 10739.369,33. Silpa tersebut akan digunakan untuk belanja desa pada tahun anggaran selanjutnya.

Berdasarkan tabel 3 dan 7 dapat dilihat bahwa anggaran pendapatan dan belanja Desa Tanglad dengan realisasi pendapatan dan belanja Desa Tanglad mengalami perbedaan. Jumlah anggaran pendapatan Desa Tanglad pada tahun anggaran 2017 sebesar $\mathrm{Rp}$. 3.062.130.464 dan jumlah anggaran belanja Desa Suana tahun anggaran 2017 
p-ISSN : 2599-1418

e-ISSN : 2599-1426

sebesar Rp.3.258.868.737,00, sedangkan jumlah realisasi pendapatan Desa Tanglad tahun anggaran 2017 sebesar Rp. 3.036.618.519,33 dan jumlah realisasi belanja Desa Tanglad tahun anggaran
Jurnal Pendidikan Ekonomi Undiksha

Volume 10 No. 1 Tahun 2018

2017 sebesar Rp. 3.025.879.150,00. Jadi selisih lebih pembiayaan anggaran tahun 2017 sebesar Rp. 10739.369,33 akan digunakan untuk belanja Desa Tanglad tahun anggaran 2018.

Tabel 8. Realisasi Pendapatan dan Belanja Desa Klumpu ( bagian barat) Tahun 2017

\begin{tabular}{|c|c|c|c|c|}
\hline \multirow[b]{2}{*}{ No } & \multicolumn{2}{|c|}{ Pendapatan } & \multicolumn{2}{|r|}{ Belanja } \\
\hline & Mata anggaran & Jumlah (Rp) & Mata anggaran & Jumlah (Rp) \\
\hline 1 & $\begin{array}{l}\text { Pendapatan asli } \\
\text { desa }\end{array}$ & $14.981 .888,76$ & $\begin{array}{l}\text { Bidang } \\
\text { penyelenggaraan } \\
\text { pemerintah desa }\end{array}$ & $705.409 .528,00$ \\
\hline 2 & Dana desa & $989.317 .874,00$ & Bidang pembanguna & $2.052 .525 .900,00$ \\
\hline 3 & $\begin{array}{l}\text { Alokasi dana } \\
\text { desa }\end{array}$ & $1.217 .790 .876,73$ & $\begin{array}{l}\text { Bidang pembinaan } \\
\text { masyarakat }\end{array}$ & $543.682 .975,00$ \\
\hline 4 & $\begin{array}{l}\text { Pajak dan } \\
\text { retribusi } \\
\text { Bantuan }\end{array}$ & $181.990 .991,00$ & $\begin{array}{l}\text { Bidang pemerdayaan } \\
\text { masyarakat }\end{array}$ & $99.334 .000,00$ \\
\hline 5 & $\begin{array}{l}\text { keuangan } \\
\text { khusus }\end{array}$ & $900.000 .000,00$ & Bidang tak terduga & 0,00 \\
\hline & Total & 3.304.081.630,49 & Total & $3.400 .952 .403,0 C$ \\
\hline
\end{tabular}

Pada tabel 8 terlihat penganggaran pendapatan Desa Klumpu bersumber dari pendapatan asli desa yang berjumlah $\mathrm{Rp}$. 14.981.888,76; dana desa sebesar Rp. 989.317.874,00; alokasi dana desa sebesar Rp. 1.217.790.876,73; pajak dan retribusi sebesar Rp. 181.990.991,00; dan bantuan keuangan khusus sebesar Rp. 900.000.000,00. Total anggaran pendapatan Desa Klumpu tahun 2017 sebesar Rp. 3.304.081.630,49. Angaran belanja Desa Klumpu yaitu bidang penyelenggaraan pemerintah desa sebesar Rp. 705.409.528,00; bidang pembanguna sebesar Rp. 2.052.525.900,00; bidang pembinaan masyarakat sebesar Rp. 2.052.525.900,00; bidang pemerdayaan masyarakat sebesar Rp. 99.334.000,00; dan bidang tak terduga sebesar Rp. 0,00. Total jumlah anggaran belanja Desa Klumpu sebesar Rp. 3.400.952.403,00, maka keuangan Desa Klumpu pada tahun 2017 mengalami defisit sebesar Rp. 96.870.772,51 dan akan dibantu dengan selisih lebih pembiayaan anggaran tahun anggaran sebelumnya yaitu tahun 2016 .

Berdasarkan tabel 4 dan tabel 8 dapat dilihat bahwa anggaran pendapatan dan belanja Desa Klumpu dengan realisasi pendapatan dan belanja Desa Klumpu mengalami perbedaan. Jumlah anggaran pendapatan Desa Klumpu pada tahun anggaran 2017 sebesar Rp. 3.324.054.491,00 dan jumlah anggaran belanja Desa Klumpu tahun anggaran 2017 sebesar Rp. 3.699.237.919, sedangkan jumlah realisasi pendapatan Desa Klumpu tahun anggaran 2017 sebesar Rp.3.304.081.630,49 dan jumlah realisasi belanja Desa Klumpu tahun anggaran 2017 sebesar Rp. 3.400.952.4033,00. Jadi jumlah defisit pendapatan Desa Klumpu tahun anggaran 2017 yang real harus ditutupi dengan selisih lebih pembiayaan anggaran Desa Klumpu tahun anggaran 2016 sebesar Rp. $96.870 .772,51$.

\section{Pembahasan}

Berdasarkan hasil penelitian dapat dijelaskan bahwa penganggaran keuangan desa pada kantor desa di Kecamatan Nusa Penida tahun anggaran 2017 terdapat pendapatan dan belanja desa. Pendapatan desa bersumber dari pendapatan asli desa, dana desa, alokasi dana desa, pajak dan retribusi, dan bantuan keuangan khusus, sedangkan belanja desa terdiri dari bidang 
penyelenggaraan pemerintah desa, bidang pembanguna, bidang pembinaan masyarakat, bidang pemerdayaan masyarakat, dan bidang tak terduga. Penganggaran keuangan desa di Nusa Penida tahun anggaran 2017 mengalami defisit dan kemudian akan dibantu dengan silpa tahun anggaran sebelumnya yaitu tahun anggaran 2016. Seluruh anggaran pendapatan dan belanja desa direncanakan dengan baik sesuai dengan RKP (rencana kerja pemerintah desa) tahun 2017.

Berdasarkan hasil penelitian yang dilihat dalam tabel realisasi pendapatan dan belanja desa di Kecamatan Nusa Penida pada tahun 2017 sebagian besar keuangan desa mengalami defisit, dikarenakan pendapatan desa lebih kecil dari jumlah belanja desa. Terjadinya defisit dikarenakan dalam perancanaannya pendapatan desa belum ditambahkan dengan silpa pada tahun 2016, namun dalam realisasi pelaksanaan belanja desa tahun 2017 silpa pada tahun 2016 ikut digunakan. Jadi defisit yang terjadi pada keuangan desa di Nusa Penida akan dibantu dengan silpa tahun 2016, karena menurut peraturan menteri dalam negeri no 114 tahun 2014 tentang pengelolaan keuangan desa silpa tahun anggaran sebelunya harus digunakan untuk belanja pada tahun anggaran selanjutnya.

Sejalan dengan penelitian yang dilakukan oleh Mondale, 2017) yang berjudul " Analisis problematika keuangan desa (studi perbandingan pada Desa Blang Kolak I dan Desa Blang Kolak II, Kabupaten Aceh Tengah)", dalam penelitian tersebut bahwa terdapat perbedaan dan kesamaan dalam pengelolaan keuangan di dua desa ini yang dimulai dari tahap perencanaan sampai dengan pelaporan dan pertanggungjawaban. Keuangan desa di Kecamatan Nusa penida mengalami perbedaan antara perencanaan dan realisasinya. Realisasi pelaksanaan keuangan desa di Kecamatan Nusa Penida tidak seimbang dimana pendapatan keuangan desa lebih kecil daripada belanja desa di Kecamatan Nusa Penida sehingga menyebabkan defisit keuangan pada tahun 2017.

\section{SIMPULAN DAN SARAN Simpulan}

Laporan Keuangan yang disusun oleh Kantor Desa di Kecamatan Nusa Penida pada tahun anggaran 2017 yang dibuat mulai dari tahap Penganggaran keuangan di beberapa desa di Kecamatan Nusa Penida tahun anggaran 2017 mengalami defisit, yaitu di Desa Kutampi Kaler Sebesar Rp. 274.580.125,75, Desa Suana sebesar Rp. 157.996.222,52, Desa Tanglad sebesar Rp. 196.738.273,00 dan Desa Klumpu sebesar Rp. $375.184 .428,00$. Realisasi pelaksanaan keuangan di beberapa desa di Kecamatan Nusa Penida tahun anggaran 2017 mengalami defisit, yaitu di Desa Kutampi Kaler Sebesar Rp. 67.321.496,81, Desa Suana sebesar Rp. 38.407.298,29 dan Desa Klumpu sebesar Rp. 96.870.772,51 sedangkan keuangan pada Desa Tanglad tahun anggaran 2016 mengalami surplus sehingga memiliki selisih lebih pembiayaan anggaran sebesar $\mathrm{Rp}$. 10.739.369,33.

\section{Saran}

Kantor Desa di Kecamatan Nusa Penida Tahun anggaran selanjutnya dalam realisasi pelaksanaan keuangannya agar menyesuaikan dengan APBD yang telah di buat dan realisasi pendapatan sebelumnya agar tidak terjadi defisit.

\section{DAFTAR PUSTAKA}

Anonim. Peraturan Menteri Dalam Negeri Nomor 113 Tahun 2014 tentang pengelolaan Keuangan Desa.

Peraturan Pemerintah Nomor 60 Tahun 2014 tentang Desa

Undang-undang Pemerintah Daerah 2008 (UU RI Nomor 12 Tahun 2008). 2008. Sinar Grafika

UU No. 12 Tahun 2008 tentang Pemerintahan

UU No. 6 Tahun 2014 tentang Desa

Mondale, T.F, Aliamin, Heru, F. 2017. "Analisis Problematika Pengelolaan Keuangan Desa 
p-ISSN : 2599-1418

e-ISSN : 2599-1426
Jurnal Pendidikan Ekonomi Undiksha

Volume 10 No. 1 Tahun 2018

(Studi Perbandingan pada Desa Blang Kolak I Dan Desa Blang Kolak II, Kabupaten Aceh Tengah)". Jurnal perspektif ekonomi Darussalam. Aceh: universitas syiah Kuala, Vol 3 (2):196-212

Sugiyono. 2005. Memahami Penelitian Kualitatif. Bandung: Alfabeta.

Widjaja. 2003. Otonomi Desa. Jakarta: Rajawali Pers. 
p-ISSN : 2599-1418

e-ISSN : 2599-1426
Jurnal Pendidikan Ekonomi Undiksha

Volume 10 No. 1 Tahun 2018 